\title{
PATTERNS OF LANDOWNERSHIP IN GAELIC MONAGHAN IN THE LATE SIXTEENTH CENTURY
}

\author{
by \\ Dr Patrick J. Duffy
}

The purpose of the following paper is to examine the pattern of landholding in Monaghan as it is reflected in the 1591 and 1606 inquisitions, to focus especially on the function of the ballybetagh in the Gaelic landholding system and to fit the resulting pattern of sept lands into the general framework of landownership as it operated in Gaelic Ireland in the late sixteenth century.

\section{The 1591 and 1606 Settlements}

The 1591 settlement of Co. Monaghan represented a stage in the evolution of government policy relating to the Gaelic Ulster area in the second half of the sixteenth century. South Ulster was a particularly crucial area in the manoeuverings for power by both Dublin and O'Neill.' The government had a special antipathy for Gaelic landholding systems, in which there was an inherent tendency not only for land to change hands frequently and for estates to be fragmented but for continuous strife, disorder and the imposition of often burdensome exactions by virtually independent Gaelic overlords. ${ }^{2}$ Short of direct plantation, which had, for example, been attempted with limited success in the Desmond lands of Munster, the government hoped to stabilise prevailing landholding arrangements by the introduction of English law. There is growing evidence, of course, that many Gaelic families were already adopting individualistic attitudes to what were traditionally clan lands. The O'Neills and their collateral branches were adopting English title to their lands; the earl of Ulster pursued a policy of personal aggrandisement so successfully that by 1603 he was recognised by the government as owning virtually the whole of Tyrone. ${ }^{3}$ Indeed opportunistic land acquisition was probably present in Monaghan in the latter half of the sixteenth century, especially when holding land by English law had the added advantage of freeing the McMahons from the overlordship of O'Neill. Ever McColla McMahon seems to have been particularly active in the late sixteenth century in consolidating personal estates. ${ }^{4}$

1. See Katherine Simms, Gaelic Lordships in Ulster in the later middle ages, unpublished Ph.d. dissertation, University of Dublin 1976, 308-330; T. O Fiaich, The O'Neills of the Fews Seanchas Ardmhacha, 7, 1973; P. J. Duffy, Population and Landholding in Co. Monaghan, unpublished Ph.D. dissertation, University College Dublin, 1976,
Chapter Two.

2. Nicholls, K., Gaelic \& Gaelicised Ireland in the Middle ages, Gill and Macmillan 1972; Butler, W. F., Confiscation in Irish history, Studies, 13 (1915). Studia Hibernica, 10, (1970)

4. O'Mórdha, P., The MacMahons of Monaghan (1500-1593), Clogher Record, (1955), 22-38; and The McMahons of Monaghan (1593-1603), Clogher Record, 1, (1956),
85-107. 
Such trends, however, were gradual and unsystematic. The 1591 settlement vas designed to systematise the landholding structure in Monaghan, by identifyng the principal landowners and allocating to them their estates under English aw. The principal lords in the newly-defined county were granted their lands in lemesne (to hold "in tail male" " "by Knight's service in capite") and to pay to the rown $7 \mathrm{~s}-6 \mathrm{~d}$ per tate. Lesser landowners were allotted their estates as freeholders inder the chief owners to hold in fee simple, free and common soccage and to pay 20 shillings per tate, out of which $7 \mathrm{~s}-6 \mathrm{~d}$ was to be paid to the crown and $12 \mathrm{~s}-6 \mathrm{~d}$ to heir superior lord. ${ }^{5}$

The 1591 division of the county was designed to abolish landholding under. Irish law, by introducing the concepts of individual possession, inheritance by orimogeniture, and by eliminating the McMahonship and any claims which could ve exercised through it on tributary or subject groups or areas. Because of the subsequent war in Ulster, the 1591 agreement was disturbed. Thus in 1606, Chichester reactivated the settlement in his journey to south Ulster to assess the status of freeholders. The 1606 division of the county was essentially similar in form and design to the 1591 settlement. ${ }^{6}$ Both agreements therefore, represented important developments for Monaghan, happening as they did on the eve of the extensive confiscations and subsequent plantation which followed the flight of the Ulster lords. Monaghan's exclusion from the Ulster Plantation had very significant implications for the development of landholding in the county in the first half of the seventeenth century.

Apart from the importance of the 1591 and 1606 settlements in illustrating a stage in the development of English policy in Ulster, both surveys also provide us with a systematic outline of landholding in Monaghan in the late sixteenth century. Although Fitzwilliam was particularly bent on eliminating the McMahonship, and thus forced some alterations in the structure of landownership $^{7}$ by reducing the lands of the traditional overlords, for example, and apart from the established practice of granting church lands to servitors, it can be assumed that the 1591 division of the county essentially replicated the structure of landholding as it had evolved under the Gaelic system by the late sixteenth century.

The 1591 survey, therefore, fossilised the Gaelic landholding system to a great extent. It also depicts the territorial manifestation of what was probably a more extensive organisation in Gaelic Ulster. The geometry of landholding as it appears in the Monaghan survey may have been repeated through much of south Ulster and as far west as Sligo and Mayo. As one of the last regions in Ireland to retain the trappings of Gaelic economy and society, comparatively uninterrupted by Anglo-Norman colonisation, sixteenth century Ulster (and Monaghan, in this case) may provide some clues to the organisation of landholding in much of Gaelic Ireland before the sweeping changes brought about by outside colonisation in the seventeenth century. ${ }^{8}$ In the particular case of Monaghan, until the mid 17th century the indigenous territorial system of landholding experienced compara-

\section{Fiants of Eliz. 5621-5674.}

The 1591 Survey of Co. Monaghan, Inquisitions, introduction xxi-xxxi.

6. The 1606 Division of Monaghan, Cal. S. P. Ire. 1606-1608, 164-187.

7. Cal. S. P. Ire. (1588-92), 3-5.

8. See J. Graham, 'Rural Society in Connacht 1600-1640', Irish Geographical Studies edited by Stephens and Glasscock, Q.U.B. 1970. 


\section{CLOGHER RECORD}

tively less disturbance than the rest of Ulster. For this reason, the Book of Survey and Distribution records for the mid-seventeenth century vestiges of the older framework of landholding, and is useful in analysing the ultimate development of the earlier system.

\section{The Geography of Gaelic landholding}

Unlike the Ulster planted counties, the early surveys of land in Co. Monaghan have no cartographic basis. They consist simply of lists of land holdings taken by inquisition. In the following analysis, these units have been mapped onto modern base maps, on the assumption that townlands and townland boundaries have not changed radically from the seventeenth century. As other evidence and the following examination indicates, this assumption is perfectly valid. ${ }^{9}$

Discontinuities between modern townlands and sixteenth century units are often the result of changes following plantation. Earlier units may have been divided or new ones created, and as often as not an easily-recognisable English placename introduced. In the parish of Ematris, for example, the 1591 tate of Lisnespynan was replaced in the eighteenth century by Fairfield Demesne. In the whole of Co. Monaghan, however, there have been relatively few of these changes. ${ }^{10}$ 'Wet boundaries', running through land of little agricultural potential, such as marsh or bog, and often therefore indeterminate in Gaelic Ireland, were subsequently defined more stringently as plantation estates developed through the eighteenth century. The Ordnance Survey sometimes created new divisions in the 1830's. It might be suggested that the rapid population growth in the countryside, which characterised the late eighteenth century in south Ulster, also resulted in subdivision of townlands. In Monaghan however, such a trend was probably only true of the mountainy Sliabh Beagh area in the north-west. As the following exercise indicates, the comparatively short-lived population explosion in the late eighteenth century had no impact on the framework of townlands in Co. Monaghan. It is also evident that the Ordnance Survey made few, if any, changes. What they found in the 1830 's was a well-developed parcellation of the landscape of the county that clearly pre-dated the seventeenth century plantations and had its roots in the Gaelic system of land organisation. The townland (or sixteenth century tate) was the ultimate building block in landholding in sixteenth
century Monaghan. ${ }^{11}$

Within the landholding system, the tate represented a unit of land reckoned to have a fixed productive capacity. There was thus a clear differential in tate size in richer as opposed to poorer regions of the county. It is probably hazardous to directly relate modern perceptions of land potential with conditions prevailing in the sixteenth century : subsequent economic development has altered the agricul-

9. Andrews, J. H., The maps of the echeated counties of Ulster 1609-10, P.R.I.A. 75C

10. See O'Mórdha, The MacMahons of Monaghan (1603-1640), Clogher Record, 2,

11. 1957, 163, for examples of some changed placenames.

11. Modern townland units in Ireland were known by a variety of local names in the medieval period-see, e.g. 'ploughlands' in Tipperary, 'gneeves' in Mayo, 'ballyboes' in Tyrone etc. 'Tate' was a term peculiar to Monaghan and Fermanagh and is preserved in such placenames as Tattyreagh. No satisfactory explanation of tate has 7, 1862 . 
tural potential of different areas. But there is a noteworthy correlation between small townlands and the richer limestone lowland extending from Glasslough to Clones on the one hand, and between large townlands and the poorer hill country of Aghnamullen, Clontibret and Muckno on the other. In a mapless society, with no surveying tradition or methods, the tate was a very adequate expression of the carrying capacity of the land.

By meticulously examining the 1591 and 1606 surveys, supplemented where necessary by the Book of Survey and Distribution (BSD) and the maps of the Down Survey, it is possible to fit the record of tates into the modern frame of townlands. ${ }^{12}$ As a result of this exercise Fig. 1 has been produced, which shows the location of ballybetaghs and church lands in Monaghan as they existed in the late sixteenth century.

In most cases, it proved relatively easy to identify most of the tates listed in the records. Thus, for example, Ballilecke Ballybetagh (No. 35) is particularly clear (modern townlands are given in parenthesis) :

$\begin{array}{ll}\text { Dromake } & \text { (Drummuck) } \\ \text { Tollenenarny } & \text { (Tullynarny) } \\ \text { Currafnagh } & \text { (? Corcaghan) } \\ \text { Gartenagh } & \text { (Gortnana) } \\ \text { Drumalow } & \text { (? Drumaclan) } \\ \text { Kiltibret } & \text { (Kiltubbrid) } \\ \text { Lisenyskie } & \text { ( } \\ \text { Brenedrome } & \text { (Brandrum) } \\ \text { Clonevarne } & \text { (Clonavarn) } \\ \text { Lecke } & \text { (Leck) } \\ \text { Tyremcdevan } & \text { (Tirmadown) } \\ \text { Tolligillan } & \text { (Tullygillen) } \\ \text { Cavaningarven } & \text { (Cavanagarvan) } \\ \text { Lisneshinnagh } & \text { (Lisnashannagh) } \\ \text { Cromlen } & \text { (Crumlin) } \\ \text { Corneglare } & \text { (Cornaglare) }\end{array}$

Ballentonie (3) proved more difficult, consisting evidently of very dispersed tates :

$\begin{array}{ll}\text { Mullagh my henaght } & \text { (? Mullaghnahegny) } \\ \text { Rathluan } & \text { (Relaghan) } \\ \text { Dyrrenevel } & \text { (Dernaved) } \\ \text { Clonekyne } & \text { (Clonkeen) } \\ \text { Dyrreclone } & \text { ? } \\ \text { Greighvasillagh } & \text { (? Greagh) } \\ \text { Mullanekaska } & \text { (Mullanacask) } \\ \text { Ardegenny } & \text { (Ardginny) } \\ \text { Nester } & \text { (? Killyloughavoy) } \\ \text { Killeloughvally } & \text { Two } 1 / 2 \\ \text { Tates } & \end{array}$

12. A printed, slightly edited version of the BSD is appendixed in Shirley's History of the County Monaghan, London, 1879. Facsimiles of the Down Survey barony maps are available from the Ordnance Survey. 


\section{CLOGHER RECORD}

$\begin{array}{ll}\text { Tonnaghes }(2 \text { tates) } & ? \\ \text { Killedonoghe } & \text { (Killydonagh) } \\ \text { Dyrrenegare } & \text { (Derrynarget) } \\ \text { Drombristie } & \text { (Drumbristan) } \\ \text { Glann } & ?\end{array}$

Ballylecke (No. 45) was reconstructed combining both the 1591 Survey and the BSD. Eight tates were listed in 1591 : Cloghan (same), Laccagh (Lackagh), Crevemartin (Cremartin), Angallo (Annyalla), Coreleigh (? Corlealackagh), Corrakyne (Corrakeen), Corloghdargan (Corleadargan), Corecaple (? part of Corlealackagh). An additional four tates can be identified in the BSD : Drumkill (Drumquill), Billeady (same), Downephelimy (Dunfelimy), Lissmckinshein (Lismagunshin). Five tates are, therefore, unaccounted for in this case.

In some cases it proved impossible to identify tates, either because of name changes, because the tate in question has disappeared, or because the tates were not specifically named in any source (as for example in the case of " 4 tates, all called by one name Ardagh"). ${ }^{13}$ In Fig. 1 unidentified tates are not of course located and uncertain tates are enclosed in broken lines. It has been possible in some cases to link unidentified tates, by process of elimination, with modern townlands. The problems created in the construction of ballybetagh boundaries by unidentified tates were offset in many cases by the accurate identification of surrounding tates. Church lands posed a problem in Fig. 1 because they were seldom listed by ballybetagh and were often dispersed over a wide area, as in the barony of Farney. Church lands were only listed by tate in the BSD (see index to Fig. 1), although they are also listed in parts of the Inquisitions of James I and
Charles I.

Altogether, ninety nine ballybetaghs are identified in Fig. 1, numbered consecutively from 1-99, and arranged by the five baronies of Truagh, Monaghan, Cremourne, Dartrey and Farney to assist identification in the accompanying index. ${ }^{14}$ In most cases in 1591 , the ballybetagh consisted of sixteen tates; in some cases ballybetaghs were divided into groups of eight tates and in a few instances into 4 tates. That sixteen tates was the norm is indicated by the fact that virtually every ballybetagh in 1591 and 1606 was listed as containing sixteen tates, although examination showed that in a few instances a different number might actually be specified. In the BSD, there was a much greater irregularity in the tate aggregates, probably reflecting some degree of disorder in the system in the early decades of the seventeenth century. The following table outlines the frequency of occurrence of ballybetaghs with varying numbers of tates in 1591,1606 and the
BSD.

13. Shirley's History and Some Account of the Territory or Dominion of Farney (London 1845) are both useful in identifying some placename changes in the period since the
Down Survey.

14. A document of 1567 refers to 66 ballybetaghs in the lands of Loghtie, Dartrie, Tallegallgan and Trough-McKena, and 36 ballybetaghs in Farney, Clancarville, Ballinelurgan and Krighe Moorne, a total of 102-Shirley, Farney, 49. 
No. of ballybetaghs in

1591 Survey

1606 Survey

BSD

$\begin{array}{ccccccccccccccc}1 & 4 & & & & 1 & & & & 36 & & 1 & & \\ 1 & 10 & & 1 & & 1 & & 1 & 2 & 31 & 4 & & & \\ & 1 & 1 & 1 & 3 & 3 & 1 & 5 & 6 & 16 & 2 & 2 & 2 & & 1\end{array}$

\section{The Barony of Truagh}

It was particularly difficult to identify the ballybetaghs in the parish of Errigle Trough. There appears to have been considerable fragmentation of lands in this area in 1591, and probably as a result of fragmented land sales in the early seventeenth century, the BSD does not refer to ballybetagh units. The ballybetagh of Portclare, held for a time by Hugh O'Neill of Dungannon in the late sixteenth century is listed in the 1591 Survey, but was in fact in Co. Tyrone. The ballybetaghs in the parish of Donagh were relatively easy to identify.

\section{The Barony of Monaghan}

Most of the ballybetaghs in Monaghan barony are easy to identify except for the ballybetaghs of Ballilurgan, Ballyneghan and Ballycaslane $(25,26,37)$ which are unmentioned in 1591, but listed in 1606 as 'Loughtee', having been previously held by the garrison at Monaghan. They are specified partly in the BSD and in a grant to Edward Blaney in $1607 .{ }^{15}$

\section{The Barony of Cremourne}

Although most of the ballybetagh names are given in 1591, the tates are very inadequately specified, so the BSD was used extensively to delineate their boundaries. Two ballybetaghs, Drumgalvin and Drum ${ }^{c}$ con $(48,49)$ were unmentioned in 1591 . They were part of the Termon of Muckno. ${ }^{16}$

\section{The Barony of Dartrey}

Dartrey is the most unsatisfactory barony in Fig. 1, due to the inability to identify the demesne lands of Brian McHugh óg McMahon. Since his estates comprised the only demesne grant in Dartrey in 1591, his five ballybetaghs presumably extend through the undivided lands in Killeevan and Aghabog parishes. As there is considerable difficulty in identifying the tates listed in 1591 and 1606, some of the ballybetaghs defined in Fig. 1 may have dubious boundaries. As a result of considerable land sales in the early seventeenth century, the ballybetaghs are not listed in the BSD for Dartrey. ${ }^{17}$ Ballymagarchan (69) and

15. Pat. Rolls James I, Vol. 1, 295.

16. MacDuinnshléibhe, P., Mucnámh and Baile na Lurgan, C.R. 1957.

17. With the exception of Ballynure ballybetagh, which was, in fact, one of the five unspecified ballybetaghs belonging to Brian McHugh óg (Fig. 1). Art óg McMahon lived in Ballynure in the 1630's. 
Ballidrumarill (75) are based on O'Mordha's conclusions about the inheritance of Rory óg McMahon in $1640 .{ }^{18}$

\section{The Barony of Farney}

The barony of Farney was excluded from the 1591 and 1606 divisions by virtue of its possession by the Earl of Essex from 1575. The information in Fig. 1 is based exclusively on the BSD which listed all the tates in Farney by ballybetagh. Due undoubtedly to the stability of ownership in Farney throughout the seventeenth century, the framework of ballybetaghs as it existed in the sixteenth century probably remained intact by the mid seventeenth century. It is probable, however, that the information on Farney was obtained from an earlier survey. The BSD data on Farney is allegedly based on the Gross Survey, but, as Simington points out, the hastily produced Gross Survey often used pre-existing surveys. ${ }^{19} \mathrm{It}$ is possible, therefore, that the outline of ballybetaghs in Farney is based on Raven's survey of the Essex property in $1634 .^{20}$

\section{Ecclesiastical Divisions}

The secular landholding structure exhibited by the ballybetaghs, was complemented by a diffuse network of church lands-termons, glebe lands and land belonging to the bishoprics of Armagh and Clogher. Because of their dispersed nature, the church lands are comparatively difficult to identify. Fig 1, however, attempts to show the extent of church land in the county. Of 150 tates listed as church land in the BSD, 76 have been reasonably satisfactorily identified. In the barony of Dartrey, apart from Clones and Killeevan parishes, there were no records of identifiable church property. The " 4 tates of Edergole" (70A) were ] , ted as secular land in 1591 and 1606. Edergole was the seventeenth century name for Ematris parish, and the townland of Edergole according to Shirley, was the site of an ancient cemetery. ${ }^{21}$ These four tates, therefore, may have historically belonged to the church. The termon of Muckno (in Cremourne barony) is listed as containing three ballybetaghs in 1591, but is identified as secular land in 1606 and the BSD. In the barony of Farney, ballybetagh no. 95 appears twice in the BSD as belonging separately to both the church of Magheross and the Earl of Essex. Bearing these qualifications in mind, Fig. 1 probably substantially understates the extent of church property in the county in the late sixteenth century.

Parish boundaries are also shown in Fig. 1, reflecting not only the spheres of influence of the local churches, but perhaps, more importantly reflecting the territorial administration of tithes. The parishes were not listed in the 1591 or 1606 surveys, which were essentially concerned with land ownership in Gaelic Monaghan. They were first used as important territorial divisions by the Civil Survey (and the BSD), to facilitate the largescale land confiscations of the mid seventeenth century. Almost all the parishes of the Co. Monaghan area can be

18. O'Mórdha, op. cit. Clogher Record (1957), 168.

19. Simington, R. G., The Civil Survey (Counties Donegal, Londonderry, and Tyrone),

20. I am indebted to Prof. John Andrews, Trinity College, Dublin for drawing my
attention to this attention to this survey.

21. Shirley, E. P., History of the County Monaghan, London 1879, 328-9. 


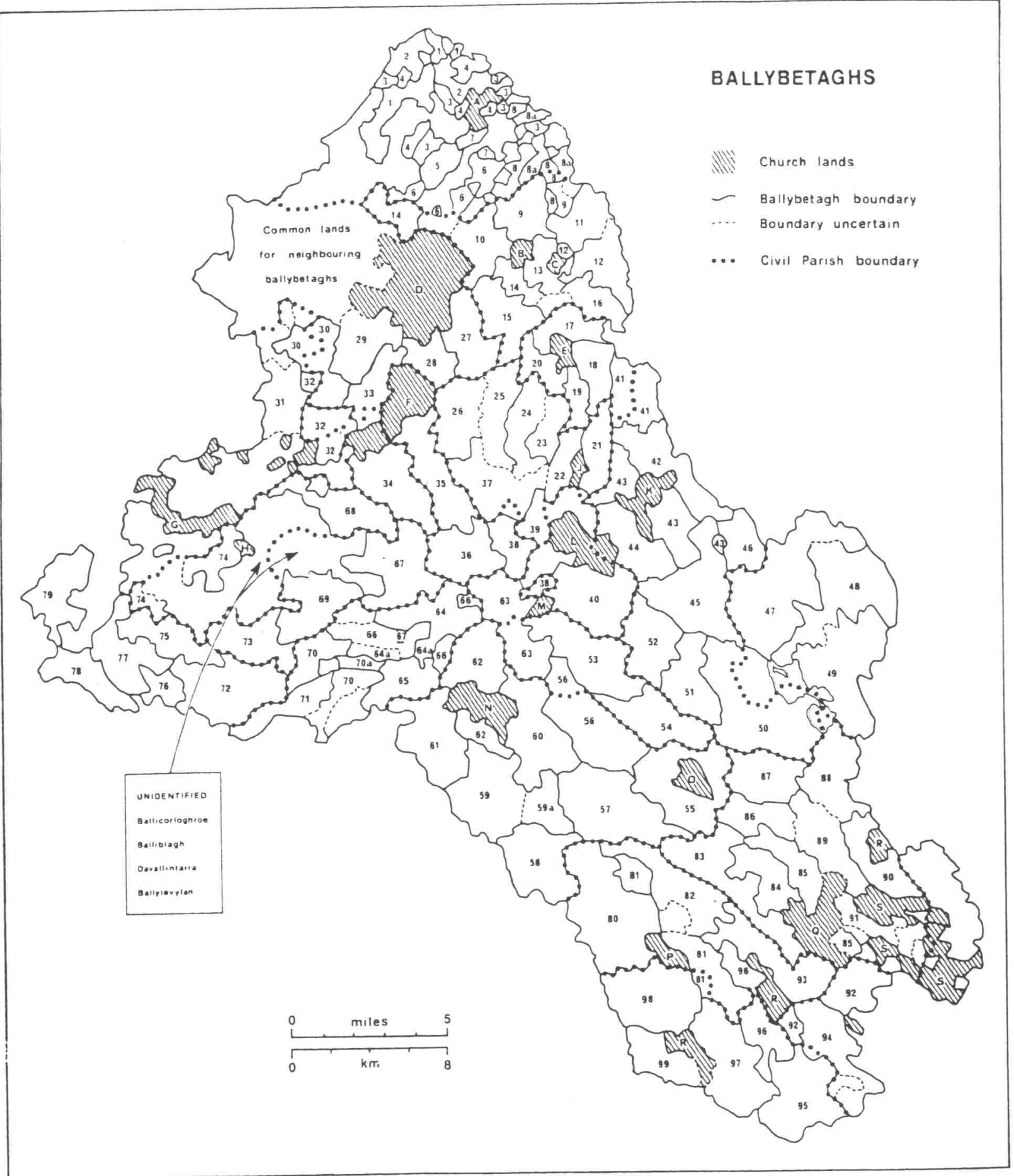


found listed by name in various papal records of the fourteenth and fifteenth centuries. Some indeed are referred to in the late twelfth century. ${ }^{22}$ But only isolated instances of specified internal denominations are given. The boundaries of the civil parishes are indicated in Fig. 1 and incorporate some changes made in the eighteenth century by the Established Church. Killeevan and Curran were established as separate civil parishes in 1767 and 1806 respectively. Since they are specified in detail in the BSD, they were clearly older divisions. Ballybay was also separated from Tullycorbet in 1796, although the nature of this division reflects an earlier boundary significance. ${ }^{23}$

It is only when the parish boundaries are superimposed on the map of ballybetaghs, that the territorial logic of secular and ecclesiastical land divisions in Gaelic Monaghan is made clear. In virtually every instance, the parish boundaries (including the eighteenth century divisions by the Established Church) correspond exactly with the ballybetagh boundaries. The parish clearly consisted of aggregates of ballybetaghs. In the few exceptional cases where ballybetaghs straddle parish boundaries, it is noticeable that the ballybetaghs follow what were probably the more ancient barony boundaries. For example, the ClontibretTehallen parish boundary divides Ballyglanka (41) into two units of eight tates; but the barony boundary includes the whole of Ballyglanka (see Fig. 1). It is possible that the parish boundary at one time corresponded with the barony boundary, but local circumstances may have divided the ballybetagh into two parishes. In the case of Ballym ${ }^{c}$ enrewe (38), in the parish of Kilmore, two tates are completely separated from the main ballybetagh and these two townlands also represent an outlier of the parish of Kilmore, completely surrounded by the parish of Tullycorbet (Fig. 1).

In every instance, therefore, the parish boundaries represent a systematic grouping of property units in Gaelic Monaghan. The civil parishes, as they were adopted by the Established Church, were obviously much older divisions of the Gaelic church. They carried with them important rights in the matter of tithes, for example, which undoubtedly ensured a stringent continuity in their boundaries through the traumatic changes of the seventeenth century. The correspondence of ballybetagh and parish boundaries, both with important property and taxation implications, is a significant feature of Gaelic territorial organisation.

\section{The Landholding system in 1591}

The territorial order that is apparent in the delimitation of ballybetaghs and their tate sub-units can throw considerable light on the nature of Gaelic landholding systems. Although the 1591 division was designed to shatter the lordship of McMahon, and to supplant it with landownership by English law, a process which involved some degree of land redistribution, as pointed out already the essential

22. See De Annatis Hiberniae (Ulster volume) containing references to parishes in the period 1413-1532. See also Lawlor, H. J., The Genesis of the Diocese of Clogher, Journal of the Co. Louth Archaelogical Society, 4 (1917), who refers to a charter of 1188 mentioning Monaghan parishes; see Shirley's History, 289.

23. In fact, the Tullycorbet-Ballybay division was a reassertion of the old barony boundary between Monaghan and Cremourne, except for half of Balleloghlaghlin (No. 63), a Cremourne ballybetagh which was included in Tullycorbet parish. 
components of the sixteenth century landholding system were established in the 1591 division.

The principal families of the McMahons, most of whom by Irish law were historically entitled to succeed to the McMahonship, were allocated relatively extensive demesne lands. Each in turn was allocated a number of freeholders from whom they were entitled to collect a tribute. As examination of the 1591 and 1606 surveys shows, the ballybetagh was clearly the basic unit of property in these divisions.

Seven principal families were allotted twenty eight ballybetaghs, ranging from 21/2 to Patrick Duff McColla McMahon to $5 \frac{1}{2}$ to Ross Bane McBreine McMahon. The Barony of Farney was excepted, but was effectively held by Ever McColla McMahon (as a tenant of sorts to the Earl of Essex); Ever McColla also held 5 ballybetaghs in demesne in the barony of Cremourne. The remaining ballybetaghs (with the exception of those in Farney) were held by freeholders : 14 under Brian McHugh óg, 111/2 under Ever McColla, 81/2 under Ross Bane, 6 under Patrick McKenna, 4 under Patrick McArt Maol, 21/2 under Patrick Duff McColla and 2 under Brian of McMahon. Finally, the lucht tighe or mensal lands of McMahon were allotted to the garrison in Monaghan, and the church lands which were never legally in the control of the McMahons, were granted to servitors, most of whom were palesmen. ${ }^{24}$

The 1606 division made a few minor alterations in the 1591 agreement. In the barony of Dartrey, Ballymagarchan (69), Ballyslaughill (73) and Ballycurren (76), formerly the freehold estate of the brother of Brian McHugh óg, were granted in demesne to three of his nephews. Ever McColla's large property in Cremourne was altered slightly by the granting of Ballilurgan and Balleknockeoliste (50) to Edward Blayney, (seneschal of Monaghan) who also received the mensal lands of McMahon. In return for this, Ever received in demesne ballybetaghs 62 and 63, formerly freeholder property held by two of his sons and a descendent of the McMahons of Monaghan barony. In the following year, Blayney also received the termon of Muckno. ${ }^{25}$

The freeholders' property did not change substantially between 1591 and 1606. In a number of cases where a freeholder had died without issue, his property was given to a servitor or a trusted Irishman. Twelve servitors thus got in most cases no more than one or two tates in a half dozen ballybetaghs in the barony of Monaghan. Elsewhere the freeholders were either the same as in 1591 or were clearly sons who had inherited the land in the meantime.

In many ways, the freeholders are the most interesting element in the 1591 division, because they throw some light back on the mechanisms of landholding in Gaelic society in the sixteenth century, and forward on the processes which were leading to the inevitable break-down of the system even before the confiscations of the mid-seventeenth century. To a great extent it is the freeholders who form the link between Gaelic landholding practices and the estate system of the nineteenth century. ${ }^{26}$ The freeholders, of whom there were over two hundred in 1591 , represented the main body of property owners in Gaelic Monaghan.

24. Hill, G. An Historical account of the Plantation of Ulster at the commencement of the seventeenth century, Belfast, 1,877, 48.

25. Inquisitions, and Hill, op. cit. 48.

26. See McCurtain, M., 'Rural Society in post Cromwellian Ireland', in Studies in Irish History edited by Cosgrove and McCartney, U.C.D., 1979. 


\section{CLOGHER RECORD}

Clearly the monies charged to them in the 1591 settlement represented an attempt by the crown officials to translate the traditional rights and obligations of the Gaelic free farming classes into forms of money rent. Subsequent sale or mortgage of their tate lands by individual freeholders in the 1620's shows, however, that they were outright owners of their property and not tenants as implied in the 1591 settlement. They were essentially the substantial farmers of the countryside, and the ballybetaghs represented the family estates or sept lands. The ballybetagh was the integral unit of property for the freeholders and the manner of its occupation by the freeholders casts considerable light on the nature of ownership and inheritance in the sept lands of Gaelic Ireland.

Ten ballybetaghs (Nos. 22, 32, 38, 48, 53, 59, 62, 69, 73 and 76) were held by single freeholders one of whom, Willis, was an Elizabethan soldier and the other, Fleming, was a Newry merchant. Apart from O'Connolly, the remainder were McMahons. A further nine ballybetaghs were each held by from two to four freeholders (mostly McMahons). But the vast majority of the remaining forty eight freehold ballyteaghs were each held by from six to sixteen freeholders.

Examination of the names of these freeholders indicates the manner by which ballybetagh units were held, for the most part, by clearly identifiable family groups. Thus, Ballevickenally (24) was held by ten McArdills; Balleclonaugre (36) was held by nine McArdills; Balleglaslagh (12) was divided among seven McQuaides.

The following was the distribution of land in Ballinecreive (56) in 1591 :

Four tates to Edmonde McMelaghlin McMahon

Two tates to Tole McMelaghlin McMahon

Two tates to Melaghlin McMelaghlin McMahon

Two tates to Edmond McOwen McMahon

Four tates to Toole McOwen McMahon

Two tates to Toole Boy McMahon

In the neighbouring ballybetagh of Ballekillawnye (54) a different McMahon group owned the land : four tates each were held by Owen, Ardell and Rosse McColla McBreine McMahon and four tates were also held by Arte McEver McMahon.

In spite of the abundance of McMahons among the freeholders, it is possible in many cases to detect the kinship links among the freeholders within the ballybetagh estates :

\begin{tabular}{|c|c|c|}
\hline \multirow{2}{*}{\multicolumn{3}{|c|}{$\begin{array}{l}\text { Balledromgowla }(70) \\
4 \text { tates }\end{array}$}} \\
\hline & & Phelim Skippie McMahon \\
\hline 1 tate & (B) & Hugh bane \\
\hline 1 tate & (C) & Patrick McColla McShane McMahon \\
\hline 2 tates & (D) & Shane McMahon McHugh roe \\
\hline 1 tate & (E) & Breine McHugh roe McMahon \\
\hline 1 tate & $(\mathrm{F})$ & Edmonde oge $\mathrm{McHugh}$ roe \\
\hline 1 tate & (G) & Melaghlin McBrian McMahon \\
\hline 1 tate & (H) & Shane McHugh McManus McMahon \\
\hline 1 tate & (I) & Bryan ballagh McHugh McManus McMahon \\
\hline 1 tate & (J) & Bryan boy McHugh McManus McMahon \\
\hline ate & (K) & Hugh McGilpatrick McHugh McManus McMah \\
\hline ate & (L) & Hugh McBrian McArt McMahon \\
\hline
\end{tabular}




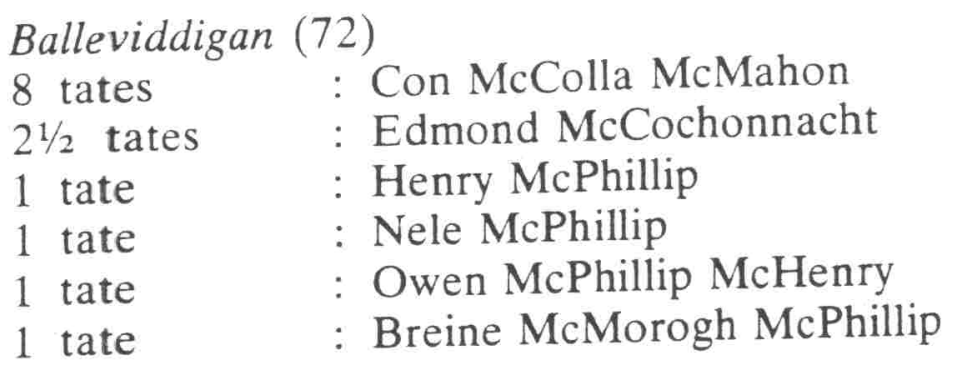

The 1606 survey affords an opportunity to look for significant changes in landholding patterns among the freeholders since 1591. Examination of the lists of freeholders indicates that there was comparative stability in the system, with tate properties remaining in the possession of the same family, and inheritance by one son apparently operating where the original owner had died. In the ballybetagh of Balledromgowla, for example, the following was the pattern of ownership of the same tates in 1606 :

(A) Thomas McBrian McMahon McThomas, "the former patentee being slain in rebellion"

(B) Donogh McHugh Bane

(C) Same as 1591

(D) Phillip McShane McMahon

(E) Mahowne McBrian McHugh roe

(F) Not given.

(G) Melaghlin McMelaghlin McBrian McMahon

(H) Edmonde Oge McMahon

(I) Brian McBrian Ballagh McHugh

(J) Art McBrian Boy McHugh

(K) Hugh McHugh McGilpatrick

(L) Hugh McEcorbe (?)

In most cases, where the 1591 owner had died, a son appears to have taken over. This pattern is repeated in every ballybetagh in the county indicating stability in both property units and possession for this, admittedly, short period of time.

\section{The Functioning of Gaelic landownership}

Although our understanding of the functioning of the Gaelic landholding system has increased greatly as a result of recent research, it is still far from complete. The following general discussion is intended to fit the Monaghan situation into the Gaelic system as it is now understood.

Landholding in Gaelic Ulster in the sixteenth century appears to have been a proto-feudal system, except that overlordship took the place of landownership. The land was held by the sept, with the most dominant sept holding the overlordship over the more inferior septs or kin-groups, and on this basis extracting tribute, dues and services from the inferior groups. The inferior septs, however, were free and their property was their own by right. The growing exactions of many of the Gaelic overlords in the sixteenth century were forcing many of the freeholders to seek the protection of alternative overlords, or English law. On the 
other hand, the dependence of the overlords on the freeholding septs to provide them with cavalry and troops placed the septs in a comparatively strong position. ${ }^{27}$ In many cases, however, the freeholders were close kinsmen (often sons or brothers) of the principal lord, so that much of the freehold property was effectively part of the dominant family's estates.

From the perspective of the chief overlord, five levels may be ascertained in the landholding system :

1. The chief lord's private family lands (held as a member of his sept or kin-group).

2. The mensal lands or lucht tighe, which traditionally provided the lord's household with food.

3. The demesne lands, which traditionally accompanied the office of lord or chief, and which were farmed by his tenants who paid him rent.

4. The freeholder's lands, from which he obtained a variety of dues and services.

5. Church lands. Church land was supposed to be free of exactions imposed by the secular lordship, although the erenaghs were increasingly under pressure from the Gaelic lords in the sixteenth century. Airghialla (Co. Monaghan after 1585) throws some light on this system. The county represented the country of "The McMahon", who was an ur-righ of O'Neill in Ulster. It was divided into baronies in 1585, which were in fact the traditional territories of the various branches of the McMahons. In the fifteenth and sixteenth centuries, the McMahonship fluctuated between the McMahons of the Barony of Monaghan and those from Farney. The McMahons reflected their geographical location in their political wavering between O'Neill and Dublin and in their periodic allegiance to English laws throughout the later middle ages.

Throughout most of the sixteenth century, the McMahonship rested with the lords of Monaghan barony, who lived in the neighbourhood of Monaghan town. Three ballybetaghs in the vicinity comprised the mensal lands of the McMahons, probably occupied by freeholding septs. All the baronies were subdivided into ballybetaghs comprising either demesne land belonging to the principal lord of the territory, or his freeholders' lands. The ballybetaghs were further subdivided by their sept-owners into sixteen-tate units which were distributed among the branches of the family group. The tates, which represented in most cases the individual farms of the freeholding population, and presumably of the tenant populations on demesne lands, were sometimes subdivided further. A multiplicity of half-tates in the territory of the McKennas of Truagh provides a glimpse of this process, although the minute fragmentation and parcellation that is evident in Connacht and north Tipperary seems generally absent from Monaghan. ${ }^{28}$

Periodic redistribution of sept land was characteristic, as Nicholls points out, with the most senior member of the sept being given the best share in the land. ${ }^{29}$ On this basis, therefore, the tate units in Monaghan changed hands within the kin

27. Nicholls, op. cit. 70; Quinn and Nicholls, 'Ireland in 1534' New History of Ireland,
Oxford 1976, 36.

28. Graham, J., 'Rural Society in Connacht 1600-1640', Irish Geographical Studies, edited by Stephens and Glasscock, Q.U.B., 1970.

W. J. Smyth, Land Values, Landownership and population patterns in Co. Tipperary, 1641-60 and 1841-50, Etudes Rurale, forthcoming 1981.

29. Nicholls, K., Some documents of Irish law and custom in the sixteenth century, Annalecta Hibernica, 26, 106-7. 
group-i.e. there would have been constantly changing ownership of tates within the ballybetagh. In this instance, however, apart from the fact that the subdivision of ballybetaghs into tates and their distribution in 1591 in varying lots among members of the group clearly indicates a system of fragmentary ownership of sept land, there is no other evidence about periodic redistribution of the land. The 1606 survey indicates that there was complete stability in tate ownership, with tates being inherited where necessary by sons of deceased owners. One must assume, therefore, that the 1591 and 1606 divisions reflected the results of the imposition of English law to stabilise landholding. However, it might also be true that at this stage the freeholders had begun to establish personal claims to their individual land (tate) units.

Two main categories of landowners were therefore characteristic of Gaelic Monaghan-(a) the chief landowners, who were politically and economically dominant and (b) the subordinate freeholders. With the increasing perception of land as a commodity by the late sixteenth century and the gradual adoption of English law, the principal McMahons were in a strong position in 1591 to translate their hereditary demesne lands into extensive private estates. Some of the demesne tenants, as Nicholls suggests were ultimately better-off than the freeholders. ${ }^{30}$ Tenants of half a ballybetagh of demesne land, for example, would probably have had undertenants, and would possibly have been financially better-off than a freeholder owning one or two tates. The actual economic difference between most of the freeholders and most of the tenants was probably quite negligible. The barony of Farney, divided into approximately twenty ballybetaghs, in 1591 consisted by law of tenants of Ever McColla McMahon, who was the chief tenant of the Earl of Essex. Most of these tenants were presumably freeholders of twenty years previously, whose title to their lands was conveniently ignored in the grant to Essex.

It might be suggested indeed that the nature of the Gaelic landholding system was such that freeholders were generally in transit to tenant status. There was constant downward mobility through the system, ${ }^{31}$ and by virtue of the inheritance system, the freeholding population was under constant pressure. Traditionally in Gaelic society, the greatest pressure on the freeholders came from the top. The lord (and by extension, his family) as a result of his right to exact tribute and taxes and to occupy the vacant land of his freeholders, often as a consequence of his capacity to exert military pressure through his créaght, ${ }^{32}$ was in a strong position to reduce the property of weaker and impoverished septs. As a result of constant fragmentation of their ballybetagh, the separate branches of the freeholding family might become progressively less able to pay the necessary exactions, or to stock their lands. With the growing importance of the economic viability and profitability of land in the early seventeenth century ${ }^{33}$ the small freeholding landowners were increasingly disadvantaged. Examination of the fate of the freeholders in Monaghan in the period up to 1640 illuminates some of the processes which operated in the previous century. By 1640 , for example, the vast

30. Nicholls, Gaelicised Ireland, 70.

31. Ibid., 11, 57; Canny, N. P., The Elizabethan Conquest of Ireland, Sussex, 1976, 24.

32. Simms, K.,'The Creaghts in Medieval Ulster', paper read in geography seminar, April 1981. Maynooth College.

33. See Clarke, A., "The Irish Economy 1600-60", A New History of Ireland, III edited by Moody, Martin and Byrne 1976. 
majority of the Monaghan freeholders had been bought out by either incoming planters or local Gaelic families. ${ }^{34}$

The lord's family was in general quite numerous and there was consequently constant pressure to seek land. The pledge or mortgage was generally the merchanism by which the process of land transfer was accomplished. ${ }^{35}$ The McMahon lords in the fifteenth and sixteenth centuries had very large families of sons who were in most cases successfully established on estates, presumably at the expense of the pre-existing freeholders. Rughraidh McMahon (died 1446) had an enormous family of eighteen sons and his father Ardgal had thirteen sons. ${ }^{36}$ As Nicholls points out, divorce, concubinage and the inheritance rights of illegitimate sons all led to expansion of the clans from the top. In this manner, the MacCathmhaoils of Clogher, for example, lost their lands and subsequently left the area. ${ }^{37}$ It was this process which resulted in a multiplicity of McMahons among the freeholders in 1591. There was, therefore, a constant expansion and contraction in the freeholding population, with new owners coming into the system from the numerous and strong ruling family, expanding in numbers, fragmenting their estates and being in turn replaced and their estates consolidated by new owners. The depressed and dispossessed freeholders were relegated to tenant status, just as the freeholders of 1591 were destined to become tenants by 1640 .

The economic pressures on the freeholders increased as the seventeenth century approached and progressed. Many of the sept lands were reduced in extent as individual freeholders and their tates hived off and were sold. There is clear evidence of very early fragmentation of lands in Errigle and Ematris parishes. By the 1620's, there was a very active land market throughout the county, with the freeholders' lands rapidly succumbing. Many of the sons of the 1591 chief grantees appear in the records as being involved in land deals. The traditional relationship between the lord and his freeholders continued in most cases up to 1640 . In 1610 , the government considered that proper settlement in Monaghan would not be accomplished "if the freeholders be not freed from the distresses and dependency of the MacMahons"' ${ }^{38}$ Ultimately, therefore, the disappearance of the small freeholding landowners was the climax of an inherent tendency in the Gaelic landholding system, where the lord's family land was expanded at the expense of the lesser families. The adoption by the Gaelic families of personal lands, and inheritance by primogeniture in the seventeenth century, meant that large Irish-owned estates were emerging by the middle of the seventeenth century. It is doubtful, however, if many of these indigenous landowners were as commercially astute as the growing band of colonial property speculators and investors who were infiltrating ti.e county from the rest of Ulster at this time.

34. Duffy, P. J., 'The territorial organisation of Gaelic landownership and its transformation in Co. Monaghan 1591-1640', Irish Geography, 1981.

35. Nicholls, op. cit.

36. See Simms, op. cit., 367; O'Mórdha, Clogher Record 1957, 148.

37. O'Dufaigh, S., The MacCathmhaoils of Clogher, Clogher Record, 2 (1957), 42-44.

38. Shirley, op. cit. 121. 


\section{CONCLUSION}

As one of the most Gaelic regions in Ireland up to the mid-seventeenth century, Monaghan county may provide useful insights into many aspects of Gaelic economy and society. In this discussion the crucial importance of the ballybetagh within the Gaelic landholding system has been demonstrated. It is noteworthy that the ballybetagh as a unit of social significance disappeared rapidly in the seventeenth century with the collapse of Gaelic landownership. This discussion, however, raises a number of additional queries about the nature of land and society in south Ulster in the sixteenth century. For example, what is the relationship between settlement patterns (especially raths) and the ballybetagh framework? The barony boundaries, especially the Cremourne-Farney boundary appear to be significant in this context.

Any analysis of population and settlement must resolve continuing puzzles about the nature and number of the rural population below the landowning class, and the extent of population mobility within the territorial framework of ballybetaghs. ${ }^{39}$ To what extent did the buailteachas tradition of summer pasturing affect the organisation of tates and ballybetaghs? Does the fragmented nature of lands in Errigle Trough parish, for example, reflect such a seasonal pattern of activity? Finally, to what extent is the Monaghan landholding system typical of Gaelic Ireland? There is no doubt that the territorial order that is evident in late sixteenth century Monaghan prevailed throughout south Ulster as far west as Donegal. How was the pattern in other parts of Ireland affected by medieval Norman colonisation? To what extent did Monaghan's frontier location on the Pale, and the interaction with the colony that this entailed, influence the landholding system? These questions will be included in a future examination of settlement and economy in this south Ulster area.

39. See Robinson, P., 'Irish settlement in Tyrone before the Ulster Plantation' Ulster Folklife, 22, 1976. 


\section{CLOGHER RECORD}

Index to Ballybetaghs (Figure 1.)

(Except where the spelling is very difficult to understand, it is taken from the 1591 Survey Otherwise the 1606 Survey or BSD are specified).

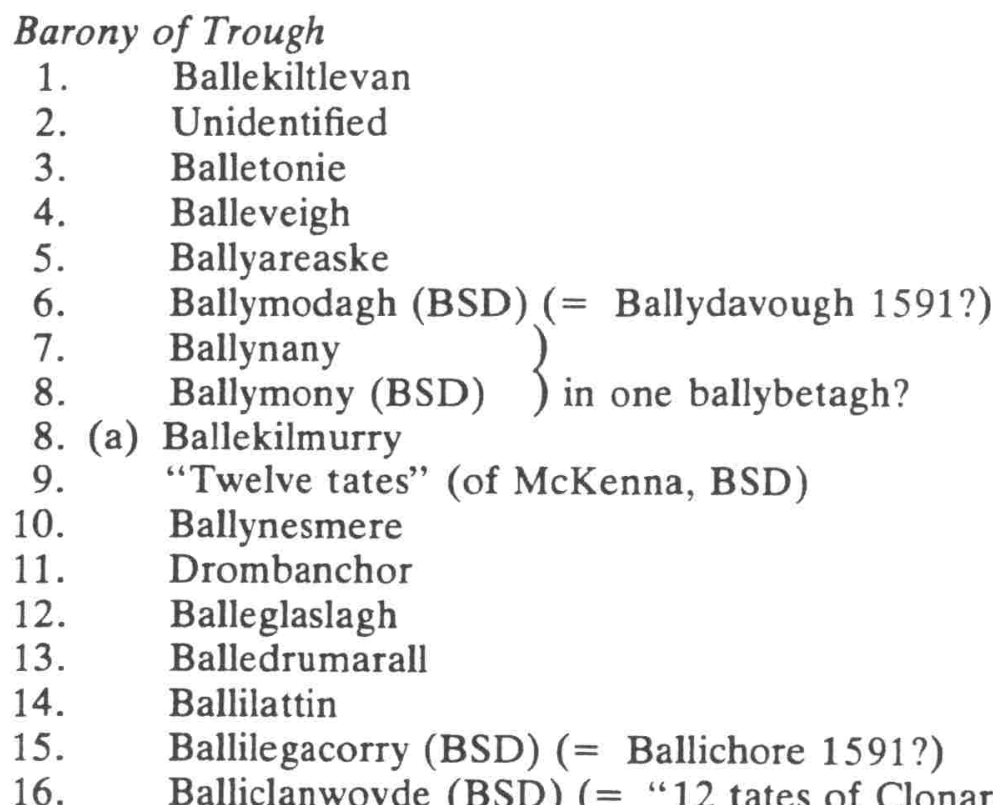

\section{Barony of Monaghan}

17. Ballineshalvie

18. Ballim c garren

19. Balleblagh (in two half sections-only one half identified in Fig. 1.)

20. Ballereogh

21. Ballyleartie (Ballyfertie, BSD)

22. Ballemorchie (Ballymurphy, BSD)

23. Balleskeaghan (Ballym ${ }^{\mathrm{c}}$ skehan, BSD)

24. Ballevickenally

25. Ballylatlurkan (BSD) (Ballilurgan, 1606)

26. Ballymechan (BSD)

27. Ballytullaghcashell

28. Ballyraconnyle

29. Ballenecorrely ( $=$ Ballim $^{c}$ turlagh, BSD)

30. Ballem ${ }^{c}$ cowlee (Ballim ${ }^{c}$ kowlan, BSD)

31. Ballytyrebrun

32. Balliclenlagh

33. Ballehue

34. Ballym ${ }^{\mathrm{c}}$ gowne

35. Ballilecke

36. Balleclonaugre

37. Ballenra (BSD) (= Ballycaslane 1606)

38. Ballym ${ }^{\mathrm{c}}$ enrewe

39. Ballenefaragh

40. Ballicorresoulagh (= Ballicorfingulas, BSD)

\section{Barony of Cremourne}

41. Balleglanka

(The eight tates in the Tehallen parish section of this ballybetagh were listed as Balliclerian in the BSD, referring to the lineage group which held this half of Balleglanka in 1591, viz., Con O'Clerian and four other O'Clerians. The remaining eight tates were held by McMahons) 
42. Ballevickenally (= Balliduffy, BSD)

43. Balleskeaghan

44. Ballenecrevie

45. Ballilecke (Ballylacky, BSD)

46. "Half ballybetagh of Cornebrock" (BSD) ("Half ballybetagh of Cargagh", 1591/ 1606)

(In this area, the townland of Tallyreagh north is still referred to locally as Cornabrock)

47. Drumaliske (BSD) (Nos. 47, 48 and 49 belonged to Muckno Termon, see note 16)

48. Drum Galvan (BSD)

49. Drum McCon (BSD)

50. Ballenelurgan (1606-2 ballybetaghs of which Balleknockeoliste (1591) was the other)

51. Balleoghill

52. Ballevicklewlie (Ballym ${ }^{\mathrm{c}}$ leholey, BSD)

53. Ballemeighan

54. Ballishean (BSD, 8 tates) (= Ballykillawney, 1606)

55. Ballenlogh

56. Ballenecrave (Ballynecrevie, BSD)

57. Ballereogh

58. Ballerawer (= Ballyfremar, BSD)

59. Balleneveaghan

59. (a) Balledromgor (1606)

60. Ballintamlaght

61. Ballenney

62. Balleportnave

63. Balleloghlaghin (Ballyloghlay, BSD)

Barony of Dartrey

64. Balleroney

64. (a) Ballederrikinard (1606)

65. Ballelisnespynan ( $1 / 2$ ballybetagh, 1591)

66. Ballevallemore

67. Balledromhurke

68. Ballehoran

69. Ballem ${ }^{\mathrm{c}}$ garchan

70. Balledromgowla

70. (a) "Four tates of Edergole"

71. Balledyrrenemoyle ( $1 / 2$ ballybetagh 1591 )

72. Balleviddigan

73. Ballyslaughill (1606)

74. Ballynure (BSD)

75. Balledromarrall

76. part of Ballecurren (1606)

77. Ballenelogh

78. unidentified

79. Ballencovenche

Barony of Farney

(from BSD)

80. Balliclevan

81. Ballidromlavan

82. Balledromgawney

83. Balliclare

84. Ballihenry 


$\begin{array}{ll}\text { 85. } & \text { Ballironyne } \\ \text { 86. } & \text { Ballikillneveagh } \\ 87 . & \text { Ballifincarne } \\ \text { 88. } & \text { Ballegartcony } \\ \text { 89. } & \text { Balletivedyny } \\ 90 . & \text { Ballitrea } \\ 91 . & \text { Ballishancough } \\ 92 . & \text { Ballitirdoone } \\ 93 . & \text { Balleclogheefe } \\ 94 . & \text { Ballidromrawer } \\ 95 . & \text { Ballidromenir (glebe land?) } \\ 96 . & \text { Ballecockavan } \\ \text { 97. } & \text { Ballydrombannon } \\ 98 . & \text { Balleskallchill } \\ 99 . & \text { Ballikinnaghan }\end{array}$

\section{Church Lands}

A. Six tates of Errigall (BSD)

B. Termon of Dundonagh (4 tates in 1591). ("Four tates of Ballilattin" in BSD).

C. Termon of Donagh (1 tate, 1591).

D. Termon of Tedavnet (16 tates 1591 known by the names of Ballem ${ }^{c}$ murrey or

E. Termon of Tehallen (6 tates, 1591).

F. Termons of Drumsnatt and Killmore (6 tates each in 1591).

G. Church lands in Clones parish (BSD).

H. Termon of Killeevan (2 tates, 1591).

J. Termon of Rackwallace (3 tates, 1591).

K. Termon of Clontibret (6 tates, 1591).

L. Termon of Tullicorbet (12 tates, 1591).

M. See of Clogher (BSD).

N. Termon of 'Aghemollen and Annye' (10 tates 1591).

O. Church lands (BSD).

P. "Tates belong to Noe ballybetagh" (BSD)—church lands?

Q. Ditto-church lands of Donaghmoyne? These are probably too extensive. The $\mathrm{BSD}$ also lists twenty one tates as glebe land belonging to the Church of Magheross.

R. Lost of these are listed separately as the ballybetagh of Ballidromenir (No. 95).

S. Lands leased from the Bishop of Armagh (BSD)-apparently concentrated in
Inniskeen parish.

The map wues not separately identify the extensive Termon of Mucknoe, described in 1591 as consisting of three ballybetaghs, which were Drum Galvan (48), Druma con (49), anc Drumaliske Galvan (47), see note 16. Termons in 1591, which could not be identified were Ballilovan ( 8 tates); "Greghlen and
the Grainge" ( 6 tates). A considerable number of the tates listed in the BSD as belonging to the See of Clogher
were unidentified. 